\title{
The mineral diversity of the Urdini Lakes and the glacial valley of the Urdina River (Rila Mountain) - an overview
}

\section{Svetoslav Petrussenko, Chavdar Karov}

National Museum of Natural History, Bulgarian Academy of Sciences, 1 Tsar Osvoboditel Blvd, 1000 Sofia, Bulgaria; e-mails: svet_petrussenko@yahoo.com; ch_karov@abv.bg

(Received: 01 October 2021; accepted in revised form: 29 October 2021)

\begin{abstract}
An overview of different types of mineralization in the area of the Urdini Lakes and the glacial valley of the Urdina River (northwestern Rila Mountain) has been made. Currently, it is the only protected area for minerals in Bulgaria. In this area, mainly pegmatite, but also skarn and alpine-type mineralizations, have been found to date. Of particular interest are the hybrid desilicified type pegmatites containing emerald, aquamarine and chrysoberyl crystals and the extremely rare native aluminum. The skarn mineralizations from this area are characterized by wollastonite, diopside, garnet (grossular, andradite), zoisite, clinozoisite, scapolite, vesuvianite and others. In the alpine-type mineralizations, well-formed crystals of quartz, adular, epidote and pyrite, as well as nests of almandine with albite, were observed as recrystallization of the minerals previously formed in the cavities of the host rocks. These cavities may also occasionally contain zeolites.
\end{abstract}

Petrussenko, S., Karov, C. 2021. The mineral diversity of the Urdini Lakes and the glacial valley of the Urdina River (Rila Mountain) - an overview. Geologica Balcanica 50 (3), 15-22.

Keywords: mineral diversity, pegmatites, Rila Mountain, Bulgaria.

\section{INTRODUCTION}

The glacial valley of the Urdina River, northwestern Rila Mountain, is well known for its beautiful and plentiful nature. It contains rare endemic species, such as the Rila primrose (Primula deorum), the Bulgarian avens (Geum bulgaricum), the rhapontic rhubarb Rheum rhaponticum, and many others (see Asenov et al., 2015, and references therein). This area is inhabited by diverse alpine fauna, including various large and small mammals, birds, reptiles and insects (ibid.). The richness of flora and fauna, as well the mineral diversity, was the reason this valley was declared a natural landmark for the protection of rare minerals, plants and animals (State Gazette, 1985). This is the first unique natural museum in Bulgaria among the rich inanimate and living natural diversity. This account is a brief over- view of the various types of mineralization from the region of the Urdina River, which still remains the only protected area for minerals in Bulgaria. The minerals were genetically listed and some of the most characteristic mineral species were illustrated.

\section{BACKGROUND AND PREVIOUS STUDIES}

The current alpine landscape of the Rila Mountain was modeled during the maximum of the Würm glaciation, after which the characteristic glacial cirques, trough valleys, pyramidal peaks, as well as many glacier lakes (Fig. 1) were formed (e.g., Yanakiev, 1957; Sinnyovsky, 2015). The glacial valley of the Urdina River, northwestern Rila, is located between the peaks Ushite, Malyovitsa, Golyam and Malak Mramorets, Dodov, Damga, 


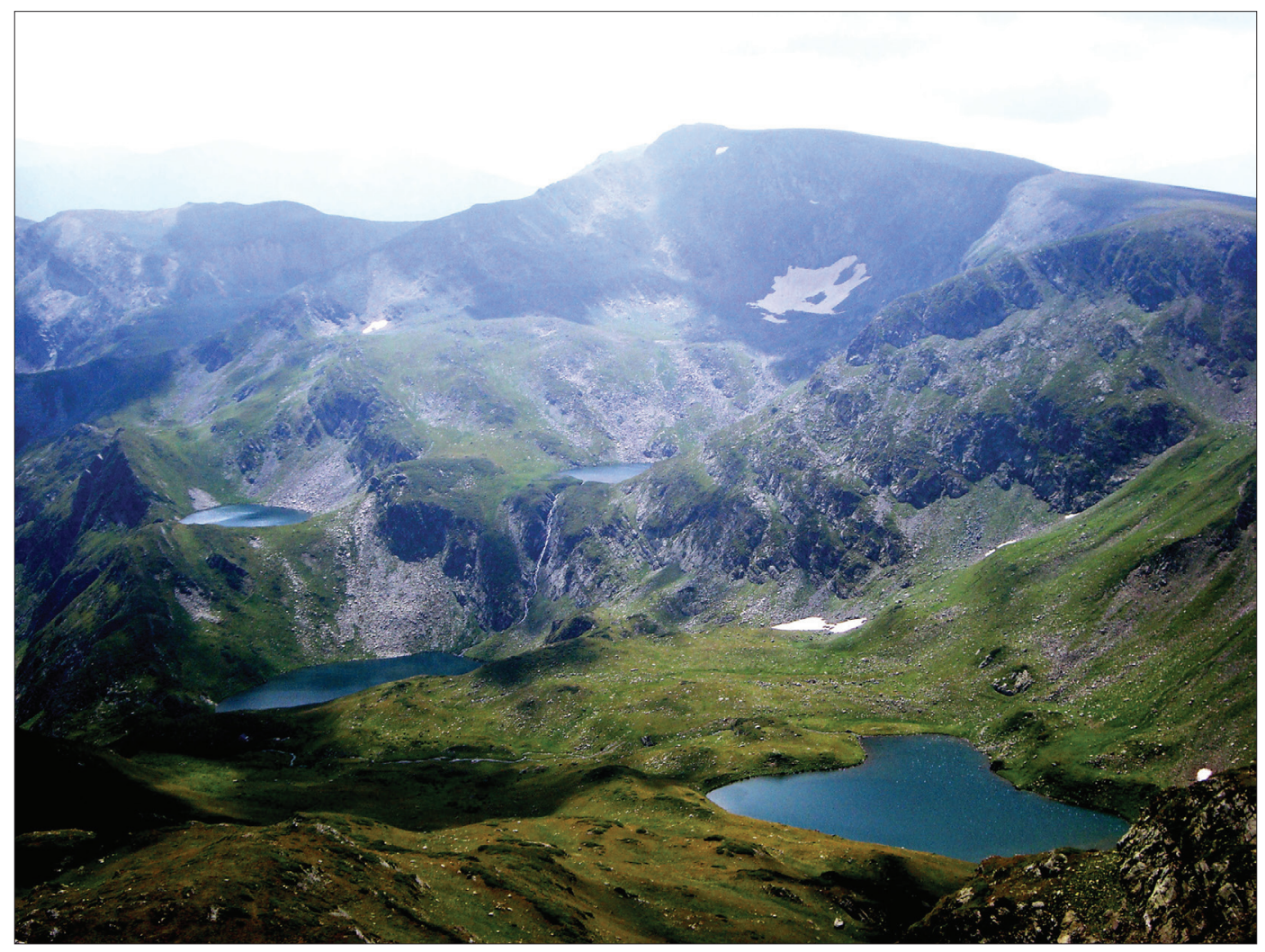

Fig. 1. Panoramic view of the Urdini cirque lakes from Damga peak, Rila Mountain.

and the ridge of Zeleni Rid. At its lowest point, it ends in the Golyama Urdina River (Fig. 2). The area of the valley is composed of various highgrade metamorphic rocks, such as biotite and amphibole-biotite gneisses, quartz-containing amphibolites, different types of magmatites and dyke rocks, as well as significant "pegmatite fields" (see Sinnyovsky, 2021, and references therein). In places, layered marble bodies and calcite-dolomite lenses occur. These lenticular bodies contain a rich association of more than 40 magnesium- and titanium-bearing minerals, e.g., forsterite, spinel, gikilite (Fig. 3a) (see also Arnaudov et al., 2012). Layered skarnoid bodies (Fig. $3 b$ ), genetically related to the regional metamorphism of clayey-calcareous sediments, are also present (Petrussenko, 1969). So far, 90 pegmatite minerals have been described from the Rila Mountain area (Arnaudov, 1975). Of them, more than 80 minerals are from the glacial valley of the Urdina River. In addition, about 35 skarn minerals, as well as minerals from ultramafic rocks and alpine-type veins, were also found (see Table 1).

On the slopes of the Zeleni Rid Ridge and the Golyama Urdina River, in gneisses, amphibolites and marbles, small lenticular bodies of harzburgites, usually chloritized and alkalized, crop out (Bonchev, 1912; Dimitrova, 1960). They are associated with chromium spinelides and talc with numerous clinochlore and tremolite veins (Fig. 4a). The chromium content gives a deep green color in emerald and fuchsite (Zhelyazkova-Panayotova et al., 1972).

\section{PEGMATITE MINERALIZATION}

Of the various types of pegmatites found in northwestern Rila, the most widely represented in the glacial valley of the Urdina River are those of microcline-plagioclase, with basic plagioclase, potassium feldspar, quartz, muscovite \pm biotite and garnet (Arnaudov, 1974). Another type of pegmatites is the so-called hybrid pegmatites, i.e., desilicified and skarnoid pegmatites (Petrussenko et al., 1966; Arnaudov and Petrussenko, 1968; Arnaudov, 1975, 1976). The desilicified ones were formed after the interaction between solutions rich in $\mathrm{Si}, \mathrm{K}, \mathrm{Na}$, $\mathrm{Ca}, \mathrm{P}, \mathrm{Be}, \mathrm{Nb}, \mathrm{Ta}$, and the basic rocks, which in turn have a contrastingly different elemental composition and are enriched in Fe, Mg, Mn, Cr, Ti, 


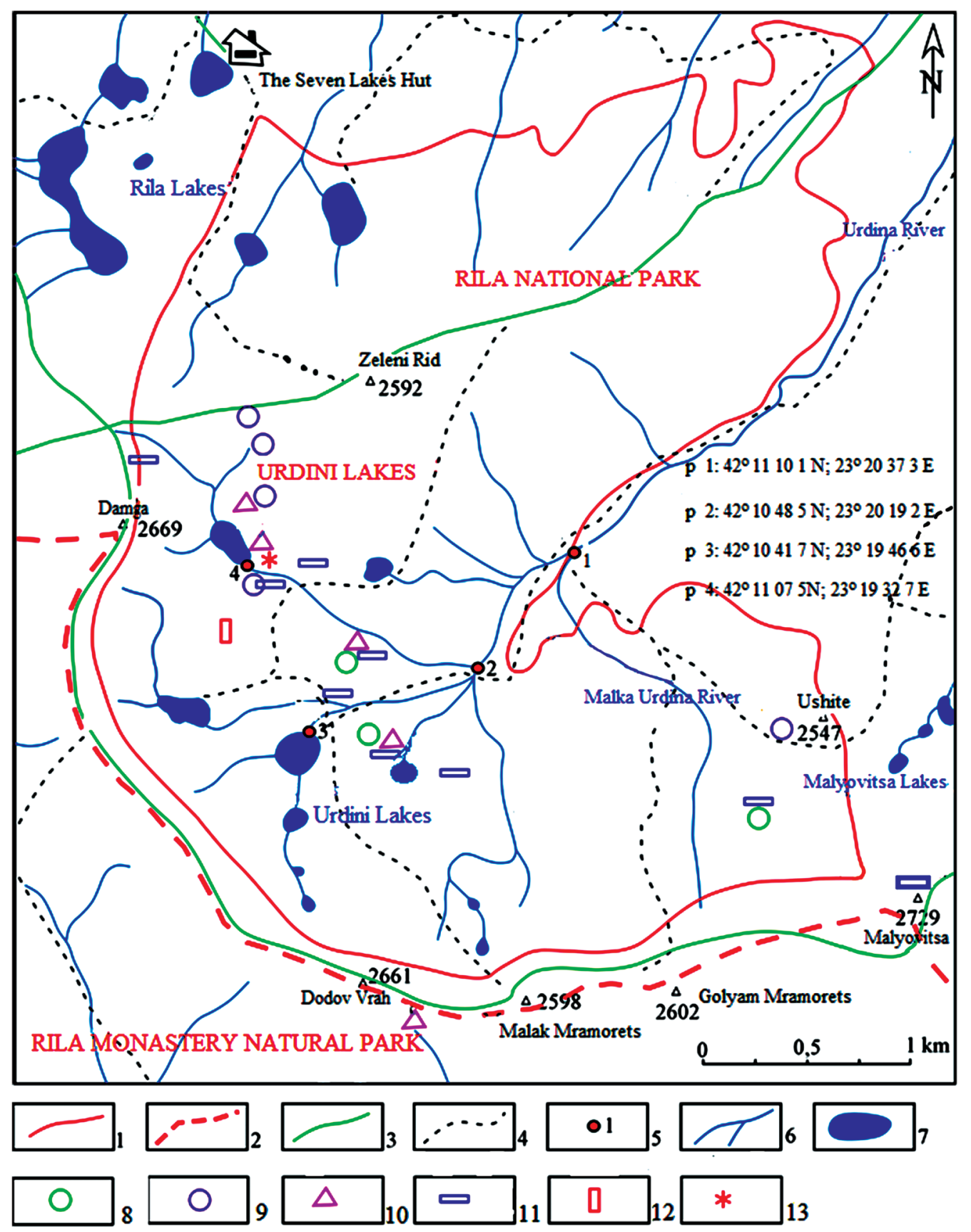

Fig. 2. Distribution of minerals in the Urdini Lakes protected area and the glacial valley of the Urdina River. Legend: 1 - border of the protected territory; 2 - border between the Rila National Park and the Rila Monastery Natural Park; 3 - marked tourist route; 4 - path; 5 - characteristic point with GPS coordinates; 6 - river; 7 - lake; 8 - alpine-type mineralization; 9 - ultrabasite with talc, tremolite and clinochlore; 10 - beryl-bearing pegmatite; 11 - skarn mineralization; 12 - emerald.

and V. Some new minerals, such as phlogopite and amphiboles, were formed. Potassium feldspar disappeared, the presence of quartz is limited, and the predominant mineral is plagioclase (oligoclase). Various titanium minerals, as well as chlorites, talc, prehnite and corundum also occur (Petrussenko et al., 1966). In these pegmatites, there are also dark green emeralds and aquamarine (Fig. $4 b-e$ ), associating with chrysoberyl (including alexandrite), fuchsite, apatite, bismuthite, as well as with the extremely rare native aluminum (Fig. $4 f$; see also Arnaudov, 2006). 
Table 1

Mineral species and varieties discovered in the glacial valley of the Urdina River, Rila Mountain

\begin{tabular}{|c|c|c|c|c|c|}
\hline $\begin{array}{l}\text { Mineral species } \\
\text { and varieties }\end{array}$ & $\begin{array}{l}\text { Distribution } \\
\text { rate }\end{array}$ & $\begin{array}{l}\text { Types of rocks } \\
\text { and mineralizations }\end{array}$ & $\begin{array}{l}\text { Mineral species } \\
\text { and varieties }\end{array}$ & $\begin{array}{l}\text { Distribution } \\
\text { rate }\end{array}$ & $\begin{array}{l}\text { Types of rocks } \\
\text { and mineralizations }\end{array}$ \\
\hline Native aluminum & $\mathrm{x}$ & 4 & Magnetite & + & $1,2,3,4,5$ \\
\hline Actinolite & + & 3,4 & Microcline & + & 1,5 \\
\hline Adular & $\mathrm{x}$ & 6 & Moissanite & $*$ & 4 \\
\hline Albite & + & 4 & Molybdenite & $*$ & 4,5 \\
\hline Amphibole & + & $1,3,5$ & Monazite & $*$ & 4 \\
\hline Anatase & $*$ & 4,6 & Muscovite & + & 1,4 \\
\hline Anthophyllite & + & 3,4 & Olivine & + & 3 \\
\hline Apatite & $*$ & $1,2,4,5$ & Oligoclase & + & 1,4 \\
\hline Beryl & & 4 & Opal & + & 6 \\
\hline - Aquamarine & * & 4 & Orthite & $*$ & 1,4 \\
\hline - Emerald & $*$ & 4 & Pennine & $\mathrm{x}$ & 3 \\
\hline - Goshenite & $*$ & 4 & Periclase & $*$ & 2 \\
\hline Margarite-Be & $*$ & 1 & Picroilmenite & $*$ & 2 \\
\hline Bismuth & $*$ & 4 & Pyrite & + & $1,4,5$ \\
\hline Bismuthinite & $*$ & 4,5 & Pyrrhotite & $*$ & 3,4 \\
\hline Bismuthite & $*$ & 4 & Rutile & $*$ & $1,2,4$ \\
\hline Vesuvianite & + & 5 & Serpentine & + & 3 \\
\hline Wollastonite & $*$ & 5 & Sillimanite & $\mathrm{x}$ & 1 \\
\hline Gahnite & $*$ & 4 & Scapolite & + & \\
\hline Galena & $\mathrm{x}$ & 4 & - Meionite & + & 4,5 \\
\hline Galenobismutite & $\mathrm{x}$ & 4 & - Mizzonite & + & 4,5 \\
\hline Geikielite & $*$ & 5 & Talc & + & $3,4,5$ \\
\hline Garnet & + & & Columbite-Tantalite & $*$ & 4 \\
\hline - Almandine & + & 1,4 & Titanite & + & $1,2,4,5$ \\
\hline - Andradite & + & 5 & Thomsonite & $\mathrm{x}$ & 6 \\
\hline - Grossular & + & 4,5 & Tremolite & + & $3,4,5$ \\
\hline - Spessartine & $*$ & 4 & Phlogopite & + & $2,3,4,5$ \\
\hline Diopside & + & $2,3,4,5$ & Fluorite & $*$ & 4 \\
\hline Kyanite & $*$ & 1,4 & Forsterite & $*$ & 2 \\
\hline Dolomite & $\mathrm{x}$ & 2,3 & Fuchsite & $*$ & 4 \\
\hline Enstatite & $*$ & 3 & Chabazite & $\mathrm{x}$ & 6 \\
\hline Epidote & + & $1,3,4,5,6$ & Chalcopyrite & $*$ & 4,5 \\
\hline Ilmenite & $*$ & $1,2,3,4,6$ & Hastingsite & $\mathrm{x}$ & 1 \\
\hline Calcite & + & $1,2,3,4,5,6$ & Hematite & $*$ & $1,4,5,6$ \\
\hline Quartz & + & $1,4,5$ & Chlorite & + & $3,4,6$ \\
\hline - Amethyst & $*$ & 6 & Chrysoberyl & $*$ & 4 \\
\hline - Milky quartz & + & 6 & Chromite & $*$ & 3 \\
\hline - Rock crystal & + & 6 & Zircon & + & $1,2,4$ \\
\hline Clinochlore & + & $3,4,6$ & Zoisite & $\mathrm{x}$ & 1 \\
\hline Clinozoisite & $*$ & 4,6 & Cirrolite & $*$ & 4 \\
\hline Columbite & $*$ & 4 & Spinel & $*$ & 2,4 \\
\hline Xenotime & $*$ & 4 & & & \\
\hline
\end{tabular}

Types of mineralizations and rocks: 1 - gneisses, amphibolites, shales; 2 - marbles, calcifications; 3 - ultrabasites; 4 - pegmatites, aplites; 5 - skarn mineralization; 6 - alpine-type mineralization. Distribution: $x$-rare; * - common; + - widespread. 

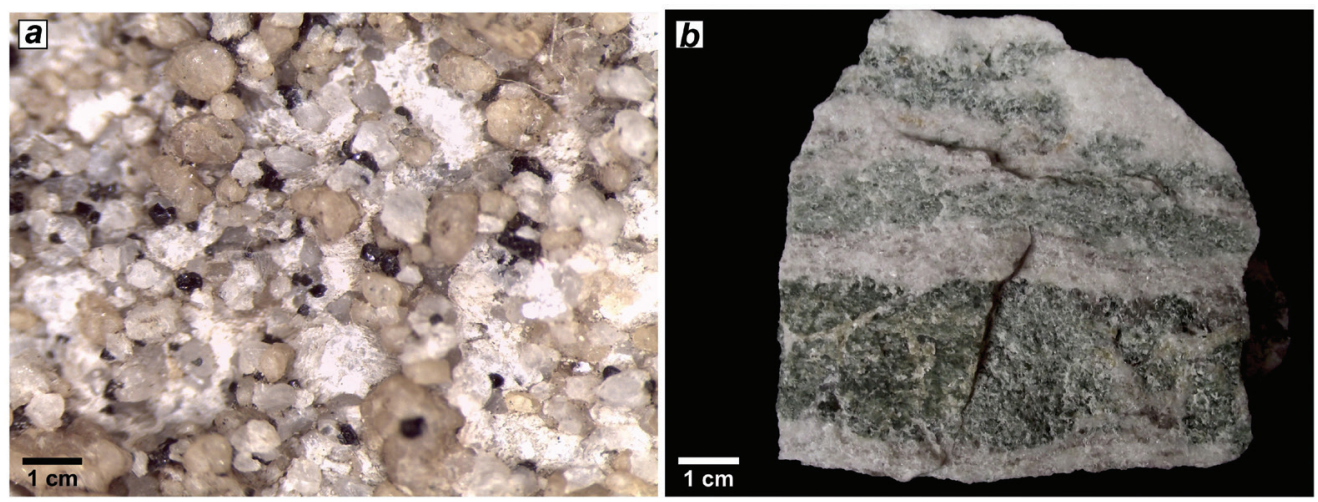

Fig. 3. Forsterite and spinel in dolomite marble (a); skarnoid containing diopside, grossular, scapolite, vesuvianite and quartz (b) from the Urdini Lakes area.
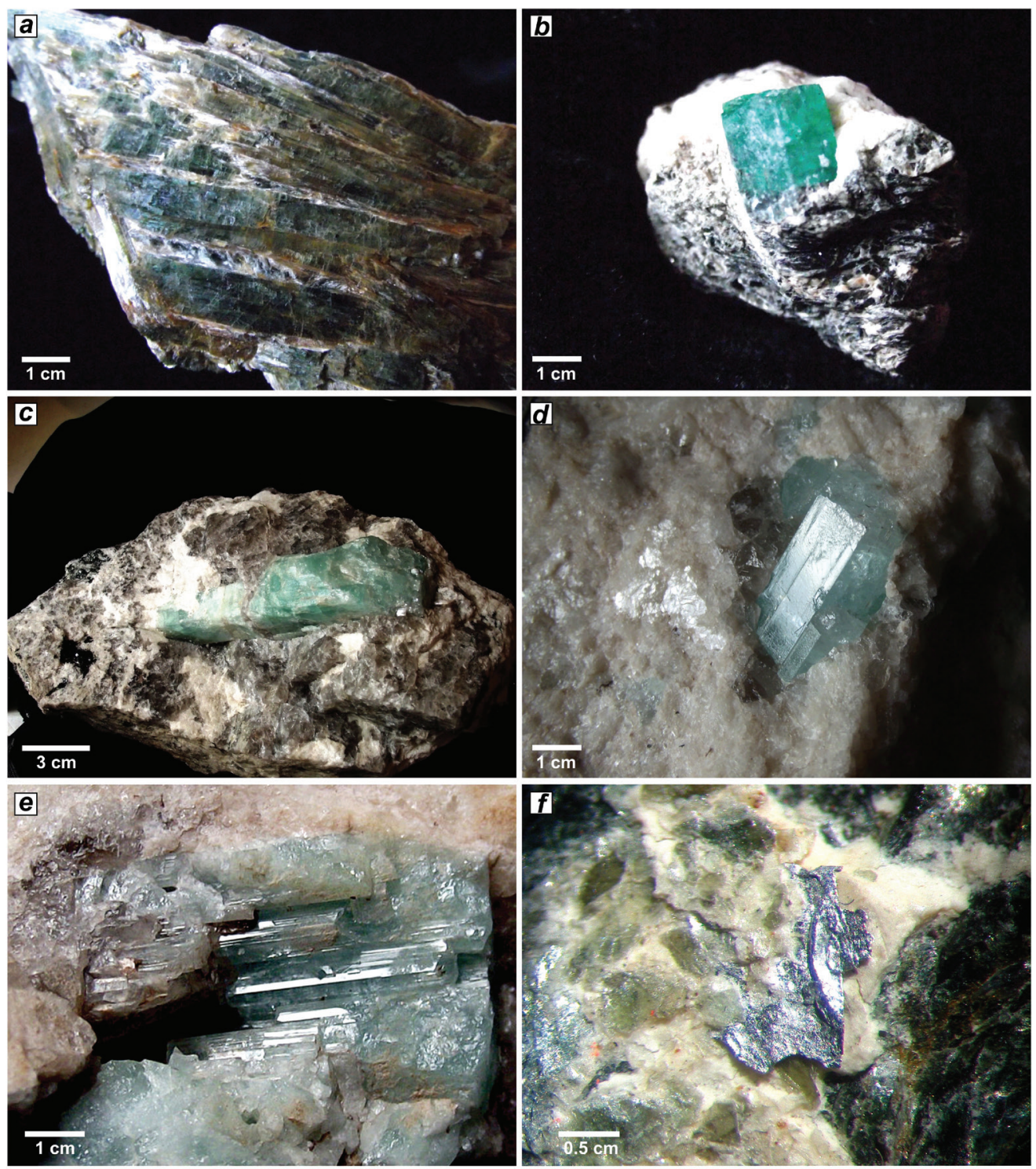

Fig. 4. Characteristic minerals from the Urdini Lakes area: $a$ ) tremolite (Zeleni Rid); b) emerald crystal with plagioclase and phlogopite; $c$ ) the largest emerald crystal found in Bulgaria; $d$ ) aquamarine crystal in pegmatite; $e$ ) emerald subparallel aggregate at the base with goshenite; $f$ ) native aluminum in desilicified pegmatite (courtesy of Asen Ignatov). 

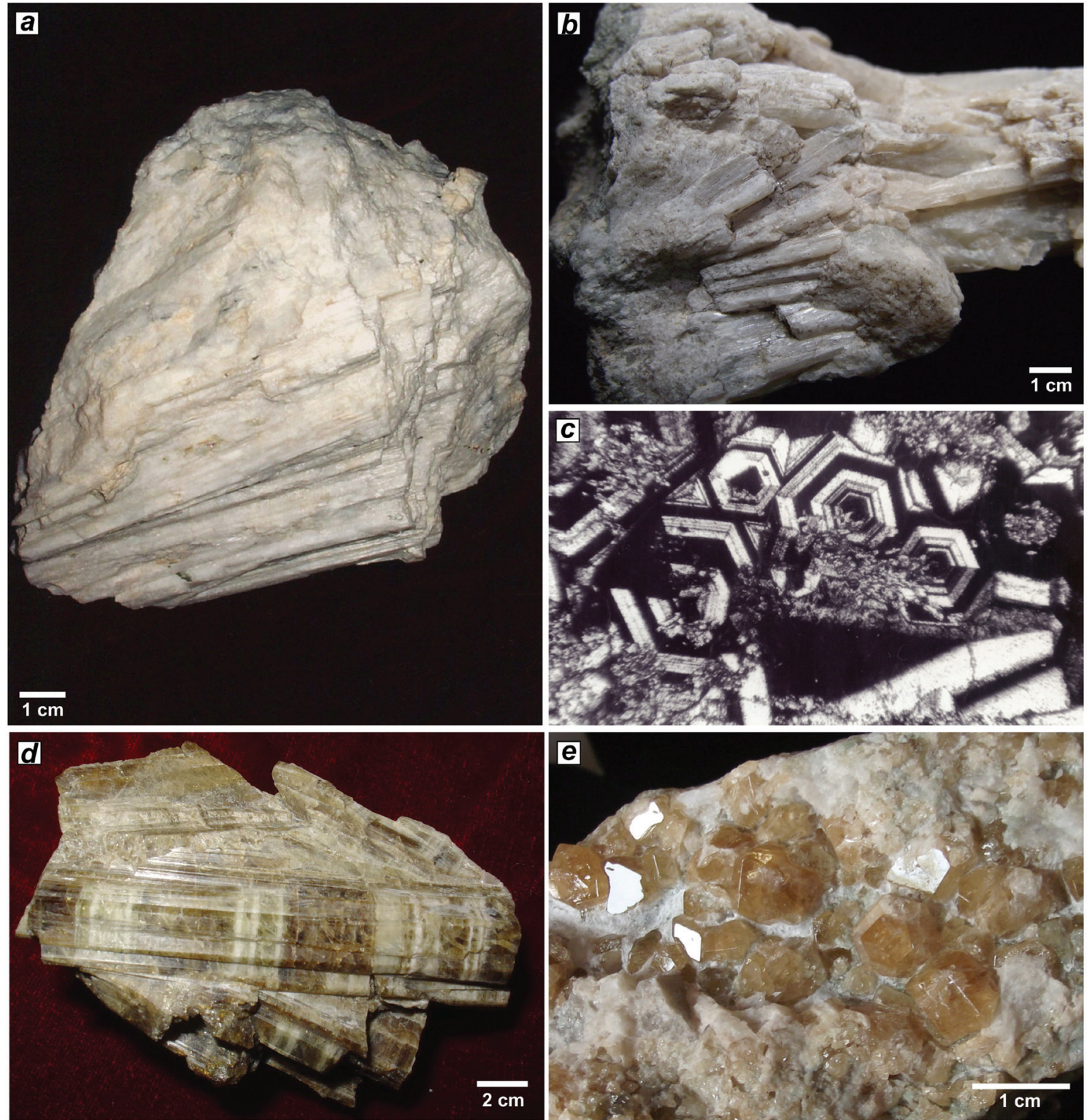

Fig. 5. Characteristic minerals from the Urdini Lakes area: a) scapolite (Golyama Urdina River); $b$ ) scapolite (Urdini Lakes); c) optically anisotropic andradite (cross-polarized light, $\times 100$ ); $d$ ) vesuvianite, long-prismatic crystal and whiskers (Golyama Urdina River); e) grossular in skarn.

\section{SKARN TYPE MINERALIZATION}

Upon the contact of pegmatite solutions, in an environment rich in $\mathrm{Ca}$ and $\mathrm{Mg}$, typical skarn minerals, such as diopside, grossular, scapolite and vesuvianite, were formed. Rarely, beryl is also present. During such interaction, K-feldspar disappeared, but plagioclase, allanite and zoisite remained. The skarns are represented by calcium-magnesium and iron-bearing minerals: wollastonite, diopside, garnet (grossular, andradite), zoisite, clinozoisite, scapolite and vesuvianite (Petrussenko, 1987). According to a previous paragenetic analysis, these minerals were formed in the temperature range of $600-540{ }^{\circ} \mathrm{C}$ at depths of $1-1.5 \mathrm{~km}$, as the source of heat and hydrothermal solutions was granite magmatism (Zharikov, 1985; Petrussenko, 1987). Under conditions of sodium metamorphosis, plagioclase in pegmatites became unstable and was replaced by scapolite (Fig. $5 a, b$ ), up to $30 \mathrm{~cm}$, and optically abnormal andradite crystals (Fig. 5c). From the alkaline metasomatic solutions, an abun- 
dant contribution of $\mathrm{Mg}, \mathrm{Al}$, $\mathrm{Ca}$ and $\mathrm{Fe}$ came, and the increased amount of volatile components, such as $\mathrm{F}$ and $\mathrm{OH}$, led to the formation of vesuvianite in the form of long-prismatic up to $10 \mathrm{~cm}$ zonal crystals and whiskers (Fig. 5d). Recrystallized grossular crystals (Fig. 5e) on diopside were also discovered.

\section{ALPINE-TYPE MINERALIZATION}

The alpine-type mineralization displays scarce occurrence. It is observed mainly as recrystallization of previously formed minerals in cavities in the form of well-formed individuals of quartz, adular, epidote, and pyrite, or as layered strips and nests of almandine with some albite in pegmatites. Thomsonite and habazite may also occur. In places, among the alpine-type of mineralization, there are light green beryl crystals grown in cavities of leached emerald, turning into water-clear crystals (goshenite) (Fig. 4e).

\section{CONCLUDING NOTES}

The area of the Urdini Lakes and the glacial valley of the Urdina River, Rila Mountain, is a site of special scientific interest, in which more than 140 different minerals have been discovered to date. Of these, pegmatite minerals are of particular significance. Of no less importance are also the skarn minerals, as well as those of the alpine-type mineralizations. A notable part of them have made the Rila Mountain region famous in the world of mineralogy and collections. Therefore, the mineral diversity of this area is an integral part of the geological heritage of the Rila-Rhodope massif, which requires careful preservation and publicity.

\section{Acknowledgements}

The authors are grateful to two anonymous reviewers for their critical reviews and comments on an early version of the manuscript.

\section{REFERENCES}

Arnaudov, V. 1975. Pegmatite types of various ages from the northwestern part of the Rhodope Massif. Geologica Balcanica 5 (4), 59-72.

Arnaudov, V. 1976. Desilicated pegmatites in the Rila Mountain. Annuaire de l'Université de Sofia 68, 129-147 (in Bulgarian, with English abstract).

Arnaudov, V. 2006. Native aluminum in desilicated pegmatite with emerald and chrysoberyl from Rila Mountain, SW Bulgaria. Geochemistry, Mineralogy and Petrology 44, 33-40.

Arnaudov, V., Petrussenko, S. 1968. Pink zoisite and pink clinozoisite from northwestern Rila. Review of the Bulgarian Geological Society 29 (3), 317-321 (in Bulgarian, with English abstract).

Arnaudov, V., Petrussenko, S., Stancheva, E. 2012. Mineralogical and chemical composition of impure marbles (magnesium-silicate calciphyres) from the Rila Mountain. Review of the Bulgarian Geological Society 73 (1-3), 5-25 (in Bulgarian, with English abstract).

Asenov, A., Vladimirov, V., Dimitrov, P. 2015. Biodiversity of the Rila National Park. Rila National Park Directorate, BIC-Bulgarian Publishing Company, 5-98 (in Bulgarian, with English abstract).

Bonchev, G. 1912. Beitrag zur Petrographie und Mineralogie des Rila-Gebirges. Review of the Bulgarian Academy of Sciences 2, 1-176 (in Bulgarian, with German abstract).

Dimitrova, E. 1960. Petrology of the crystalline plinth of northwestern Rila Mountain. Travaux sur la Géologie de Bulgarie, Série Géochimie, Minéralogie et Pétrologie 1, 199-257 (in Bulgarian).
Petrussenko, S. 1969. Scapolite from the Rila Mountain. Bulletin of the Geological Institute, Series Geochemistry, Mineralogy and Petrography 18, 153-160 (in Bulgarian, with English abstract).

Petrussenko, S. 1987. Skarn mineralizations in the Malyovitsa part of the Rila Mountain. Habilitation Thesis, Bulgarian Academy of Sciences, Sofia, 171 pp. (in Bulgarian).

Petrussenko, S. 2018. Minerals of the Rila Mountain. Minno Delo i Geologiya 5-6, 42-51 (in Bulgarian, with English abstract).

Petrussenko, S. 2002. Vesuvian aus Karbonatskarne im Rila Gebirge. Historia naturalis bulgarica 14, 145-156 (in Bulgarian, with German abstract).

Petrussenko, S.I., Kostov, R.I. 1992. The Precious and Decorative Minerals of Bulgaria. Bulgarian Academy of Sciences Publishing House, Sofia, 90 pp. (in Bulgarian, with English summary).

Petrussenko, S., Zhelev, V. 2003. Expert Assessment of the Urdini Lakes Natural Protection Site, Rila. Ministry of Environment and Water, Sofia, 20 pp. (in Bulgarian).

Petrussenko, S., Arnaudov, V., Kostov, I. 1966. Emerald pegmatite from the Urdini Lakes, Rila Mountain. Annuaire de l’Université de Sofia 59 (1), 247-268 (in Bulgarian).

Sinnyovsky, D. 2015. Würm glacier formations and mountain landscapes in the Rila Mountain, Bulgaria. $15^{\text {th }}$ International Multidisciplinary Scientific GeoConference SGEM 2015, Proceedings 1, 529-536.

Sinnyovsky, D. 2021. Precambrian metamorphites as part of the petrographic diversity of the Rila Geopark. Review of 
the Bulgarian Geological Society 82 (1), 11-19 (in Bulgarian, with English abstract), https://doi.org/10.52215/rev. bgs.2021.82.1.3.

State Gazette, 1985. Urdini Lakes. Committee for Environmental Protection at the Bulgarian Council of Ministers. Promulgated in State Gazette No. 28 of April 9, 1985 (in Bulgarian).
Yanakiev, K. 1957. Soil and geomorphological studies in the Valley of the Urdina River of the Rila Mountain. Annual of the Institute for Civil Engineering 15, 227-282 (in Bulgarian). Zhelyazkova-Panayotova, M., Petrussenko, S., Iliev, Z. 1972. Mineralogy of the skarns from the Seven Rila Lakes region. Annuaire de l'Université de Sofia 64 (1), 147-176 (in Bulgarian, with English abstract). 